\title{
EFFECTS OF HAEMOPERFUSION ON SELECTED INDICES OF BLOOD BIOCHEMISTRY IN SHEEP
}

\author{
H. SEIDEL, P. BARTKO, G. KOVÁČ, I. PAULÍKOVÁ, O. NAGY \\ Department of Internal Diseases of Ruminants and Swine, \\ University of Veterinary Medicine, Košice, Slovak Republic
}

Received August 1, 1997

Accepted January 15, 1998

\begin{abstract}
Seidel H.. P. Bartko, G. Kovác, I. Paulíková, O. Nagy: Effects of Haemoperfusion on Selected Indices of Blood Biochemistry in Sheep. Acta vet. Brno 1997. 66: 213-218.

The aim of this work was to evaluate the clinoptilolite as a cartridge for haemoperfusion columns. Changes in haematological indices and blood plasma macro-elements were evaluated during haemoperfusion in sheep with the use of zeolitic and commercial haemoperfusion columns. Haemoperfusions were done in two groups of sheep $(n=6)$ for 2 hours. In the first group, commercial haemoperfusion columns HEMASORB $400 \mathrm{C}$ filled with active charcoal were used. In the second group, the columns used were filled with sodium form of natural zeoliteclinoptilolite partially saturated with potassium chloride. During 2 hours of haemoperfusion significant decrease in numbers of leukocytes and thrombocytes $(\mathrm{P}<0.01)$ were found in both types of columns. There were no significant differences between the groups, except for the number of thrombocytes and plasma sodium concentration in the blood leaving the zeolitic columns with significantly lower values after $30 \mathrm{~min}\left(134.3 \pm 28.9\right.$ vs. $251.0 \pm 55.4 \mathrm{G}^{\mathrm{l}} \mathrm{l}^{-1}, \mathrm{P}<0.01$; and $144.17 \pm 9.13$ vs. $157.17 \pm 7.36 \mathrm{mmol}^{-1}, \mathrm{P}<0.05$; respectively) compared with commercial HEMASORB columns. However, final evaluation of biocompatibility of zeolitic haemoperfusion columns will require more detailed research.
\end{abstract}

Haemoperfusion, active charcoal, clinoptilolite, blood indices, calcium, magnesium, sodium, potassium, phosphorus, sheep

Haemoperfusion may be the method of choice in therapy of various intoxications. It is based on sorption of toxic substances during extracorporeal blood flow through detoxifying columns. The columns are filled with different sorbents such as active charcoal or synthetic resins. For the haemoperfusion purposes neutral resins are used with the sorption capability depending upon the sorbent's surface and physical properties. Amberlites (copolystyren-divinylbenzenes) are the most frequent resins used for haemoperfusion (Kováč 1993). In intoxications, the toxic substances present in the blood are retained by these sorbents during haemoperfusion.

Zeolites are crystalline aluminosilicates with tetrahedral framework structure enclosing cavities occupied by cations and water molecules, both of which have enough freedom of movement to permit cation exchange and reversible dehydration (Sherry 1993). Ion-exchange capability of zeolites is the primary function of substitution of four-valent silicon by three-valent aluminium. The higher degree of substitution, the higher deficiency of positive charge, and the higher number of cations needed for the maintenance of electric neutrality (Mumpton and Fishman 1977; Mumpton 1984).

The use of natural zeolites was studied in various areas of human activities. Sorption of radioisotopes by zeolites, particularly of $\mathrm{Cs}$ and $\mathrm{Sr}$, was reported by several authors. This property is employed in purification of waste waters from nuclear power stations (Franta et al. 1994) as well as in prevention or therapy of experimental contamination of animals (Forberg et al. 1989; Mižík et al. 1989; Vavrová et al. 1991; Musatovova et al. 1993; and others). 
Natural clinoptilolite has also high selective affinity to ammonium (B artko et al. 1983; Hlavay et al. 1988; Papad opoulos et al. 1996) and some heavy metals cations such as $\mathrm{Pb}$, and $\mathrm{Cd}$ (Blanchard et al. 1984; Seidel and Vrzgula 1989; Vrzgula and Seidel 1989; Pond et al. 1993). There are some indications that natural clinoptilolite is able to absorb aflatoxin B1. D vořák (1989) reported $60 \%$ sorption of aflatoxin $\mathrm{B}_{1}$ by natural zeolite in vitro. Similar results were recorded by TomasevicCanovic et al. (1993). Clinoptilolite was also shown to have partial protective effect in organophosphate intoxication in rats (Mojžiš et al. 1994; Ništiar et al. 1984) and sheep (Kováč et al. 1995).

Because of the aforementioned sorption and ion-exchanging capabilities of zeolite. the aim of this work was to evaluate the clinoptilolite as a cartridge for haemoperfusion columns.

\section{Materials and Methods}

In the experiment we used clinoptilolite-rich tuff from the zeolite deposit at Nižný Hrabovec. Slovakia. Chemical composition (as determined by X-ray spectrophotometry) of the zeolitic tuff was $\mathrm{SiO}_{2}, 69.22: \mathrm{MgO}, 0.75 ; \mathrm{TiO}_{2}, 0.18 ; \mathrm{K}_{2} \mathrm{O}, 2.48: \mathrm{Al}_{2} \mathrm{O}_{3}, 14.33 ; \mathrm{Na}_{2} \mathrm{O}, 0.97 ; \mathrm{CaO}, 3.40$ wt. \%; and As and $\mathrm{Pb},<0.001$ wt. \% (Kozáč et al. 1982). The tuff contained about 60-65 wt.\% clinoptilolite (as calculated from its cation-exchange capacity) and lesser amounts of cristobalite, plagioclase. quartz, and volcanic glass (X-ray diffraction analysis). The clinoptilolite-rich tuff had a cation-exchange capacity of $0.86 \mathrm{meq} / \mathrm{g}$ (Kozáč and Očenáš 1982).

Haemoperfusions were carried out in 12 Merino sheep after preceding insertion of intravenous catheters $(1.5 \times 2.0 \mathrm{~mm})$ into both jugular veins, and intravenous administration of heparin (250 U/kg b.m.) for $2 \mathrm{~h}$ (Seidel et al. 1992). Approximately $5 \mathrm{~min}$ before haemoperfusion the animals were placed in a special restraining equipment. Dialyzation monitor CHIRADIS A (Chirana Stará Turá, Slovak Republic) was used with commercial columns HEMASORB 400 C (OPS Kolín, Czech Republic) filled with active charcoal ( 1 st group, $n=6$ ), and columns filled with zeolitic tuff ( 2 nd group. $\mathrm{n}=6$ ). Following previous experiments in vitro (non-published). sodium form of zeolite (particle size 2-4 $\mathrm{mm}$ ) was used, partially saturated with potassium chloride hecause of great affinity of the zeolite to potassium. Parallel blood samples (leaving both the animal and the column) were taken at $0,30,60,90$. and $120 \mathrm{~min}$ of the perfusion. At the same intervals body temperature, pulse and respiratory rates, as well as general state of the animals were checked. Samples of blood were analyzed by blood analyzer SERONO PLUS for haematological variables (Er-erythrocytes, Lc-leukocytes. Hb-haemoglobin, PCV-packed cell volume). Thrombocyte (Tc) counts were determined by routine miscroscopical method. Plasma concentrations of $\mathrm{Ca} . \mathrm{Mg}, \mathrm{Na}$. and $\mathrm{K}$ were determined by AAS (Perkin Elmer, $4100 \mathrm{ZL}$ ). Plasma concentrations of inorganic $P$ were determined by colorimetric method (Bio-La, Lachema Brno). The results are expressed as an average $(x)$ and standard deviation ( $\pm s)$. Significance of the differences between the two groups was assessed by Student's t-test.

\section{Results}

Clinical examination of experimental animals revealed no changes in body temperature. However, an increased pulse rate (up to $122 / \mathrm{min}$ ) was found. At the beginning of haemoperfusion respiratory rate about $45 / \mathrm{min}$ was recorded. It later decreased to physiological values $(24 / \mathrm{min}$ at $120 \mathrm{~min})$. In some animals of both groups, during the haemoperfusion moderate diarrhoea occurred.

Average values of the haematological indices are shown in Tables 1 and 2 . In both types of columns the decreasing numbers of leukocytes and thrombocytes were observed $(\mathrm{P}<0.01)$. 
Table 1

Average values of haematological indices after haemoperfusion through commercial columns HEMASORB $400 \mathrm{C}$

\begin{tabular}{|c|c|cc|cc|cc|cc|cc|}
\hline $\begin{array}{c}\text { Time } \\
(\mathrm{min})\end{array}$ & & \multicolumn{2}{|c|}{ Er (T/1) } & \multicolumn{2}{c|}{ Lc $(\mathrm{G} / 1)$} & \multicolumn{2}{c|}{ Hb (g/dcl) } & \multicolumn{2}{c|}{ PCV (1/1) } & \multicolumn{2}{c|}{ Tc (G/1) } \\
animal & column & animal & column & animal & column & animal & colum & animal colum \\
\hline 0 & $\mathrm{x}$ & 7.45 & & 5.68 & & 8.57 & & 0.34 & & 420.3 \\
& $\pm \mathrm{s}$ & 2.17 & & 1.78 & & 2.80 & & 0.08 & & 100.1 \\
\hline 30 & $\mathrm{x}$ & 5.82 & 5.88 & 4.08 & 3.18 & 7.98 & 7.35 & 0.31 & 341.0 & 251.0 & \\
& $\pm \mathrm{s}$ & 2.19 & 2.20 & 1.01 & 0.95 & 1.46 & 1.09 & 0.05 & 0.06 & 92.5 & 55.4 \\
\hline 60 & $\mathrm{x}$ & 7.47 & 7.72 & 3.38 & 2.92 & 8.24 & 8.42 & 0.31 & 0.33 & 260.0 & 172.0 \\
& $\pm \mathrm{s}$ & 1.60 & 1.59 & 2.08 & 1.24 & 1.46 & 1.53 & 0.07 & 0.07 & 102.2 & 34.3 \\
\hline 90 & $\mathrm{x}$ & 7.45 & 7.00 & 3.04 & 2.86 & 7.66 & 7.32 & 0.29 & 0.28 & 217.2 & 163.6 \\
& $\pm \mathrm{s}$ & 1.63 & 1.26 & 1.62 & 1.03 & 1.50 & 1.04 & 0.06 & 0.06 & 70.1 & 35.8 \\
\hline 120 & $\mathrm{x}$ & 6.68 & 6.41 & 2.94 & 3.16 & 7.46 & 7.10 & 0.29 & 0.28 & 181.2 & 139.6 \\
& $\pm \mathrm{s}$ & 1.37 & 1.76 & 1.24 & 1.37 & 1.62 & 1.81 & 0.06 & 0.07 & 52.4 & 49.6 \\
\hline
\end{tabular}

Table 2

Average values of haematological indices after haemoperfusion through columns filled with clinoptilolite-rich tuff

\begin{tabular}{|c|c|cc|cc|cc|cc|cc|}
\hline $\begin{array}{c}\text { Time } \\
\text { (min) }\end{array}$ & & \multicolumn{2}{|c|}{ Er (T/1) } & \multicolumn{2}{c|}{ Lc $(\mathrm{G} / 1)$} & \multicolumn{2}{c|}{$\mathrm{Hb}(\mathrm{g} / \mathrm{dcl})$} & \multicolumn{2}{c|}{$\mathrm{PCV}(1 / 1)$} & \multicolumn{2}{c|}{$\mathrm{Tc}(\mathrm{G} / 1)$} \\
animal & column & animal & column & animal & column & animal & column & animal column \\
\hline 0 & $\mathrm{x}$ & 7.09 & & 6.78 & & 7.88 & & 0.29 & & 409.3 \\
& $\pm \mathrm{s}$ & 1.32 & & 2.47 & & 0.91 & & 0.06 & & 96.2 & \\
\hline 30 & $\mathrm{x}$ & 7.66 & 6.92 & 4.27 & 4.15 & 8.3 & 7.87 & 0.32 & 0.31 & 273.7 & 134.3 \\
& $\pm \mathrm{s}$ & 1.32 & 1.32 & 1.91 & 1.57 & 0.85 & 0.82 & 0.03 & 0.03 & 45.1 & 28.9 \\
\hline \multirow{2}{*}{60} & $\mathrm{x}$ & 7.39 & 7.07 & 3.20 & 2.90 & 8.62 & 8.52 & 0.33 & 0.33 & 194.0 & 138.0 \\
& $\pm \mathrm{s}$ & 0.87 & 1.49 & 1.14 & 0.77 & 0.90 & 1.34 & 0.04 & 0.05 & 72.9 & 51.8 \\
\hline 90 & $\mathrm{x}$ & 7.46 & 6.76 & 2.62 & 2.72 & 8.23 & 7.72 & 0.33 & 0.32 & 186.3 & 115.8 \\
& $\pm \mathrm{s}$ & 0.94 & 1.41 & 1.62 & 1.34 & 0.76 & 1.26 & 0.04 & 0.05 & 65.9 & 42.2 \\
\hline 120 & $\mathrm{x}$ & 7.03 & 6.16 & 2.86 & 2.66 & 7.86 & 7.68 & 0.30 & 0.31 & 154.0 & 116.4 \\
& $\pm \mathrm{s}$ & 1.22 & 1.63 & 0.81 & 1.07 & 0,07 & 0.76 & 0.03 & 0.04 & 36.6 & 69.8 \\
\hline
\end{tabular}

However, there were no significant differences between the groups, except the number of thrombocytes in the blood leaving the zeolitic column with significantly lower values after 30 min $(\mathrm{P}<0.01)$ compared with commercial HEMASORB columns.

Mean values of macroelements are presented in Tables 3 and 4.

Table 3

Average values of plasma macroelement levels after haemoperfusion through commercial columns HEMASORB 400 C

\begin{tabular}{|c|c|c|c|c|c|c|c|c|c|c|c|}
\hline \multirow{2}{*}{$\begin{array}{c}\text { Time } \\
(\mathrm{min})\end{array}$} & animal & \multicolumn{2}{|c|}{$\begin{array}{l}\mathrm{Ca}\left(\mathrm{mmol} \cdot \mathrm{1}^{-1}\right) \\
\text { column animal }\end{array}$} & \multicolumn{2}{|c|}{$\begin{array}{l}\mathrm{Mg}\left(\mathrm{mmol} . \mathrm{I}^{-1}\right) \\
\text { column animal }\end{array}$} & \multicolumn{2}{|c|}{$\begin{array}{l}\mathrm{Na}\left(\mathrm{mmol} .^{-1}\right) \\
\text { column animal }\end{array}$} & \multicolumn{2}{|c|}{$\begin{array}{l}\mathrm{K}\left(\mathrm{mmol}^{-1}\right) \\
\text { column animal }\end{array}$} & \multicolumn{2}{|c|}{$\begin{array}{l}\mathrm{P}\left(\mathrm{mmol} . \mathrm{1}^{-1}\right) \\
\text { column }\end{array}$} \\
\hline & $\begin{array}{c}\mathrm{x} \\
\pm \mathrm{s}\end{array}$ & $\begin{array}{l}2.073 \\
0.229\end{array}$ & & $\begin{array}{l}1.000 \\
0.199\end{array}$ & & $\begin{array}{c}153.67 \\
6.35\end{array}$ & & $\begin{array}{l}4.748 \\
0.586\end{array}$ & & $\begin{array}{l}1.727 \\
0.484\end{array}$ & \\
\hline 30 & $\begin{array}{c}\mathrm{x} \\
\pm \mathrm{s}\end{array}$ & $\begin{array}{l}2.045 \\
0.135\end{array}$ & $\begin{array}{l}1.720 \\
0.426\end{array}$ & $\begin{array}{l}0.945 \\
0.238\end{array}$ & $\begin{array}{l}0.838 \\
0.247\end{array}$ & $\begin{array}{l}156.33 \\
8.55\end{array}$ & $\begin{array}{l}157.17 \\
7.36\end{array}$ & $\begin{array}{l}4.507 \\
0.354\end{array}$ & $\begin{array}{l}3.987 \\
0.500\end{array}$ & $\begin{array}{l}1.448 \\
0.434\end{array}$ & $\begin{array}{l}1.492 \\
0.440\end{array}$ \\
\hline 60 & $\begin{array}{c}\mathrm{x} \\
\pm \mathrm{s}\end{array}$ & $\begin{array}{l}1.980 \\
0.175\end{array}$ & $\begin{array}{l}1.950 \\
0.275\end{array}$ & $\begin{array}{l}0.940 \\
0.181\end{array}$ & $\begin{array}{l}0.872 \\
0.218\end{array}$ & $\begin{array}{c}155.20 \\
3.56\end{array}$ & $\begin{array}{c}153.60 \\
4.22\end{array}$ & $\begin{array}{l}4.168 \\
0.294\end{array}$ & $\begin{array}{l}4.166 \\
0.397 \\
\end{array}$ & $\begin{array}{l}1.418 \\
0.498 \\
\end{array}$ & $\begin{array}{l}1.474 \\
0.445 \\
\end{array}$ \\
\hline 90 & $\begin{array}{c}x \\
\pm s\end{array}$ & $\begin{array}{l}2.094 \\
0.396\end{array}$ & $\begin{array}{l}1.916 \\
0.340\end{array}$ & $\begin{array}{l}0.924 \\
0.217\end{array}$ & $\begin{array}{l}0.866 \\
0.191\end{array}$ & $\begin{array}{c}153.20 \\
6.26\end{array}$ & $\begin{array}{l}155.80 \\
5.22\end{array}$ & $\begin{array}{l}4.244 \\
0.397\end{array}$ & $\begin{array}{l}3.892 \\
0.306\end{array}$ & $\begin{array}{l}1.416 \\
0.500\end{array}$ & $\begin{array}{l}1.392 \\
0.471\end{array}$ \\
\hline 120 & $\begin{array}{c}x \\
\pm s\end{array}$ & $\begin{array}{l}1.914 \\
0.217\end{array}$ & $\begin{array}{l}1.880 \\
0.277\end{array}$ & $\begin{array}{l}0.874 \\
0.161\end{array}$ & $\begin{array}{l}0.748 \\
0.176\end{array}$ & $\begin{array}{c}154.20 \\
4.44\end{array}$ & $\begin{array}{c}152.20 \\
5.93\end{array}$ & $\begin{array}{l}3.838 \\
0.749\end{array}$ & $\begin{array}{l}3.634 \\
0.552\end{array}$ & $\begin{array}{l}1.414 \\
0.555\end{array}$ & $\begin{array}{l}1.442 \\
0.543\end{array}$ \\
\hline
\end{tabular}


Table 4

Average values of plasma macroelement levels after haemoperfusion through columns filled with clinoptilolite-rich tuff

\begin{tabular}{|c|c|c|c|c|c|c|c|c|c|c|c|}
\hline $\begin{array}{l}\text { Time } \\
(\mathrm{min})\end{array}$ & & \multicolumn{2}{|c|}{$\begin{array}{r}\mathrm{Ca}\left(\mathrm{mmol} \cdot \mathrm{1}^{-1}\right) \\
\text { animal column }\end{array}$} & \multicolumn{2}{|c|}{$\begin{array}{r}\mathrm{Mg}\left(\mathrm{mmol} . \mathrm{1}^{-1}\right) \\
\text { animal column }\end{array}$} & \multicolumn{2}{|c|}{$\begin{array}{l}\mathrm{Na}\left(\mathrm{mmol} . \mathrm{1}^{-1}\right) \\
\text { animal column }\end{array}$} & \multicolumn{2}{|c|}{$\begin{array}{c}\mathrm{K}\left(\mathrm{mmol} . \mathrm{1}^{-1}\right) \\
\text { animal column }\end{array}$} & \multicolumn{2}{|c|}{$\begin{array}{l}\mathrm{P}\left(\mathrm{mmol} . \mathrm{1}^{-1}\right) \\
\text { animal column }\end{array}$} \\
\hline 0 & $\begin{array}{l}x \\
\pm s\end{array}$ & $\begin{array}{l}1.933 \\
0.368\end{array}$ & & $\begin{array}{l}0.993 \\
0.196\end{array}$ & & $\begin{array}{c}151.83 \\
10.07\end{array}$ & & $\begin{array}{l}3.947 \\
0.640\end{array}$ & & $\begin{array}{l}1.547 \\
0.401\end{array}$ & \\
\hline 30 & $\begin{array}{c}x \\
\pm s\end{array}$ & $\begin{array}{l}1.912 \\
0.311\end{array}$ & $\begin{array}{l}1.430 \\
0.388\end{array}$ & $\begin{array}{l}1.035 \\
0.197\end{array}$ & $\begin{array}{l}1.058 \\
0.319\end{array}$ & $\begin{array}{l}153.00 \\
11.71\end{array}$ & $\begin{array}{l}144.17 \\
9.13\end{array}$ & $\begin{array}{l}4.048 \\
0.779\end{array}$ & $\begin{array}{l}3.542 \\
2.436\end{array}$ & $\begin{array}{l}1.522 \\
0.301\end{array}$ & $\begin{array}{l}1.588 \\
0.540\end{array}$ \\
\hline 60 & $\begin{array}{l}x \\
\pm s\end{array}$ & $\begin{array}{l}1.855 \\
0.347\end{array}$ & $\begin{array}{l}1.508 \\
0.491\end{array}$ & $\begin{array}{l}0.997 \\
0.184\end{array}$ & $\begin{array}{l}0.992 \\
0.235\end{array}$ & $\begin{array}{l}153.33 \\
11.98\end{array}$ & $\begin{array}{l}145.33 \\
10.86\end{array}$ & $\begin{array}{l}3.843 \\
0.680\end{array}$ & $\begin{array}{l}3.270 \\
2.153\end{array}$ & $\begin{array}{l}1.587 \\
0.631\end{array}$ & $\begin{array}{l}1.613 \\
0.393\end{array}$ \\
\hline 90 & $\begin{array}{l}x \\
\pm s\end{array}$ & $\begin{array}{l}1.850 \\
0.361\end{array}$ & $\begin{array}{l}1.510 \\
0.381\end{array}$ & $\begin{array}{l}0.978 \\
0.180\end{array}$ & $\begin{array}{l}0.947 \\
0.221\end{array}$ & $\begin{array}{l}153.00 \\
11.26\end{array}$ & $\begin{array}{l}148.93 \\
12.42\end{array}$ & $\begin{array}{l}3.743 \\
0.588\end{array}$ & $\begin{array}{l}2.962 \\
1.785\end{array}$ & $\begin{array}{l}1.572 \\
0.504\end{array}$ & $\begin{array}{l}1.630 \\
0.350\end{array}$ \\
\hline 120 & $\begin{array}{c}x \\
\pm s\end{array}$ & $\begin{array}{l}1.874 \\
0.178\end{array}$ & $\begin{array}{l}1.646 \\
0.308\end{array}$ & $\begin{array}{l}0.930 \\
0.173\end{array}$ & $\begin{array}{l}0.932 \\
0.203\end{array}$ & $\begin{array}{l}151.40 \\
10.95\end{array}$ & $\begin{array}{l}151.40 \\
16.68\end{array}$ & $\begin{array}{l}3.370 \\
0.671\end{array}$ & $\begin{array}{l}2.508 \\
1.603\end{array}$ & $\begin{array}{l}1.590 \\
0.355\end{array}$ & $\begin{array}{l}1.664 \\
0.378\end{array}$ \\
\hline
\end{tabular}

Similarly, we found no significant differences between the groups, except the initial concentration of potassium and plasma concentration of sodium in the blood leaving the zeolitic column with significantly lower values after $30 \mathrm{~min}(\mathrm{P}<0.01)$ compared with commercial HEMASORB columns.

\section{Discussion}

To our knowledge, there is no literary information on the use of natural zeolite for haemoperfusion. Therefore we cannot compare our results with those of other authors.

During the haemoperfusion we observed some problems. We suggest that changes in pulse and respiratory rates as well as occurrence of moderate diarrhoea may be related to the stress of the animals restrained in a special equipment.

Another problem was that with decreased blood flow or in case of interruption of haemoperfusion, blood coagulation occurred, being more pronounced with zeolitic columns. In human medicine, for the commercial columns HEMASORB blood flow rate $150-200 \mathrm{ml} / \mathrm{min}$ is recommended (critical value $50 \mathrm{ml} / \mathrm{min}$ ). Because of the capacity of jugular vein, the maximum blood flow rate $70-80 \mathrm{ml} / \mathrm{min}$ achieved in our experiment may have contributed to increased blood clotting. Other possible factor involved in blood coagulation is the surface of natural zeolite. In the commercial columns sorbent particles are coated with hydrophilic polymer (poly/2-hydroxyethyl methacrylate). This polymer is permeable for substances of molecular weight up to 6000 , and prevents direct contact between blood elements, plasma proteins, and the sorbent.

For biochemical analyses we chose haematological indices and plasma concentrations of macroelements since blood counts are probably among the most important factors for general assessment of the column biocompatibility; and, on the other hand, in macroelements marked changes might be expected because of strong affinity of clinoptilolite to large cations. In this experiment we did not observe marked differences in haematological variables between commercial columns and columns filled with noncoated natural zeolite.

Similarly, no marked changes were observed in plasma concentrations of macroelements ( $\mathrm{Ca}, \mathrm{Mg}, \mathrm{Na}, \mathrm{K}, \mathrm{P})$. However, because of great affinity of clinoptilolite to potassium (in vitro experiments - not published) sodium form of clinoptilolite was partially saturated with potassium $(\mathrm{KCl})$ before the use for haemoperfusion. Ju g g i (1971) reported similar problem with the use of cation exchange columns in the treatment of ammonia intoxication in dogs. 
They used sodium form of cation exchange Amberlite. Because this resin caused severe disturbances in blood electrolytes, they developed a mixture of sodium, potassium, calcium, and magnesium forms of the resin. This resin mixture has been shown to be effective in correcting ammonium chloride-induced hyperammonaemia in dogs without any disturbances in other cationic substances of the blood. Terai et al. (1996) reported the same situation with an exchange resin for sodium, which is capable of rapidly decreasing an elevated serum potassium level, but has not been used clinically because of subsequent electrolyte abnormalities. The authors prepared the sodium/calcium/calcium $/ \mathrm{magnesium}$ exchange resin mixture specifically to remove potassium from the blood. Haemoperfusion through this resin mixture column for 2 hours reduced elevated plasma potassium concentrations (from $6.7 \pm 1.1$ to $3.5 \pm 0.6 \mathrm{mmol}^{-1} \mathrm{l}^{-1}$ ) in anephric dogs without any side effects on other blood electrolytes.

From the practical point of view, the clinoptilolite (or the fraction of its exchangeable cations) could be specifically adjusted, or a mixture of various cationic forms of the clinoptilolite prepared.

In summary, comparison of a commercial haemoperfusion column filled with active charcoal and a column filled with clinoptilolite showed no marked differences in haematological and macro-mineral profiles during the haemoperfusion in sheep. However, the final evaluation of biocompatibility of zeolitic column will require more detailed research. Moreover, suitable therapeutic indications need to be selected. There is also a need to consider the use of synthetic precisely characterized zeolite instead of natural one.

\section{Vplyv hemoperfúzie na niektoré biochemické ukazovatele v krvi oviec}

V práci sme porovnávali zmeny hematologických ukazovatelov a makroelementov krvnej plazmy u oviec počas hemoperfúzie s použitím zeolitových a komerčných hemoperfúznych kolón. Hemoperfúzii sme podrobili dve skupiny oviec $(n=6)$ počas 2 hodín. $V$ prvej skupine sme použili komerčné hemoperfúzne kolóny HEMASORB $400 \mathrm{C}$ plnené aktívnym uhlím. $\mathrm{V}$ druhej skupine boli použité kolóny naplnené sodnou formou prírodného zeolituklinoptilolitu čiastočne saturovaného chloridom draselným. Počas dvojhodinovej hemoperfúzie sme $\mathrm{v}$ oboch skupinách zaznamenali signifikantný pokles počtu leukocytov a trombocytov $(\mathrm{P}<0.01)$. Medzi skupinami sme nezistili signifikantné rozdiely sledovaných ukazovateIov okrem 30. minúty hemoperfúzie, kedy boli v skupine so zeolitom v krvi

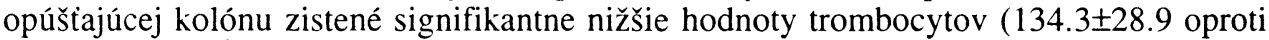

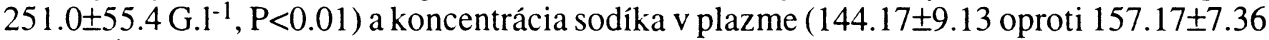
mmol. $\left.\mathrm{l}^{-1}, \mathrm{P}<0.05\right)$. Napriek tomu, konečné posúdenie biokompatibility zeolitových hemoperfúzných kolón si bude vyžadovat další podrobnejší výskum.

\section{References}

BARTKO. P., VRZGULA, L., KOVÁĊ,G., BLAŽOVSKÝ, J., PROSBOVÁ, M., REICHEL, P., PAULÍKOVÁ I. 1983: Clinical and laboratory studies of zeolite in pigs (In Slovak). Research Report. Záverečná správa VŠV Košice. 1983, 154 p.

BLANCHARD G.,MAUNAYE M.,MARTIN G. 1984: Removal of heavy metals from waters by means of natural zeolites. Water Res. 18: 1501-1507

DVOŘÁK, M. 1989: Schopnost bentonitu a prírodního zeolitu adsorbovat aflatoxin z tekutého prostředí. Vet. Med. (Praha). 34: 307-316

FORBERG, S.. JONES, B., WESTERMARK, T. 1989: Can zeolites decrease the uptake and accelerate the excretion of radio-caesium in ruminants? Sci. Total Environ. 79: 37-41

FRANTA. P., KUCA, L., SANTAROVÁ, M., VACKOVÁ, E., KVASNICOVÁ, M. 1994: Decontamination of accidental wastes from Czech nuclear energy stations (In Czech). Bezpečnost Jaderné Energie. 1: 343-349 
HLAVAY, J., INCZÉDY, J., FOLDI-POLYÁK, K., ZIMONY, M. 1988: Pilot plant study for removal of ammonia from drinking water with natural zeolite. In Occurrence, Properties, and Utilization of Natural Zeolites, D. Kalló and H.S. Sherry (eds.), Akadémiai Kiadó, Budapest, 1988: 483-490

JUGGI. J.S. 1971: Haemoperfusion through cation exchange columns in the treatment of ammonia intoxication in dogs, Proc. Soc. Exp. Biol. Med. 137: 39-42

KOVÁC. A. 1993: Hemodialyzačná liečba v praxi. Osveta, Martin, 320 p.

KOVÁC̆, G., BARTKO, P., VRZGULA, L., REICHEL, P., NIŠTIAR, F., MOJŽIŠ, J., SEIDEL, H. 1995: Application of clinoptilolite during organophosphate intoxication in sheep. Natural Zeolites ${ }^{\circ}$ 93, Occurrence, Properties, Use, D.W. Ming and F.A. Mumpton (eds.), Comm. Natural Zeolites, Brockport, New York, 1995: 459-466

KOZÁĆ. J., OČENÁŠ, D. 1982: Determination of clinoptilolite content in zeolitic tuffits (In Slovak). Mineralia Slov. 14: 549-552

KOZÁĆ, J., OĆENÁŠ, D., RUSNAK, D., AND HOPPAN, J. 1982: Mineralogy, characteristic properties and utilization possibilities of zeolitic tuffite from Nižný Hrabovec (East Slovakia) (In Slovak). Mineralia Slov. 14: $263-275$

MIŽÍK, P.. HRUŠOVSKÝ, J., TOKOŠOVÁ, M. 1989: Effects of natural zeolite on excretion and distribution of radiocesium in rats (In Slovak). Vet. Med. (Praha) 34: 467-474

MOJŽIŠ, J., NIŚTIAR, F., KOVÁČ, G.. MOJŽIŠOVÁ, G. 1994: Preventive effect of zeolite in intoxication by VX substance in rats (In Slovak). Vet. Med. (Praha) 394: 443-449

MUMPTON, F.A., FISHMAN P.H. 1977: The application of natural zeolites in animal science and aquaculture. J. Anim. Sci. 45: 1188-1203

MUMPTON, F.A. 1984: Flammae et fumus proximi sunt: The role of natural zeolites in agriculture and aquaculture. In Zeo-Agriculture: Use of Natural Zeolites in Agriculture and Aquaculture, W.G. Pond, and F.A. Mumpton (eds.), Westview Press, Boulder, Colorado: 3-27

MUSATOVOVA, O., VAVROVÁ, M., MITRO, A., BARTHA, S. 1993: In vivo studies of the ability of clinoptilolite to prevent the transfer of environmental $\mathrm{Sr}$ and Cs into sheep's milk. ZEOLITE'93, 4th International Conference on the Occurrence, Properties, and Utilization of Natural Zeolites, Boise-Idaho, June 20-28, 1993: 145-146

PAPADOPOULOS, A., KAPETANIOS, E.G., LOIZIDOU, M. 1996: Studies on the use of clinoptilolite for ammonia removal from leachates. J. Environ. Sci. Health A - Sci. 316: 211-220

POND, W.G., ELLIS, K.J., KROOK, L.P., SCHOKNECHT, P.A.1993: Modulation of dietary lead toxicity in pigs by clinoptilolite. ZEOLITE'93, 4th International Conference on the Occurrence, Properties, and Utilization of Natural Zeolites, Boise-Idaho, June 20-28: 170-172

SEIDEL, H., VRZGULA, L. 1989: Sorption of heavy metals by natural zeolite (clinoptilolite) from water (In Slovak). PoInohospodárstvo 8: 729-730

SEIDEL. H., BARTKO, P., PAULÍKOVÁ, I., BENKOVÁ, E., BALDOVIČ, R. 1992: Technical aspects of haemoperfusion in small ruminants (In Slovak). Scientific symposium with international participation .,Actual Problems in Diagnosis, Prevention, and Therapy of Internal Diseases in Ruminants“, Košice, 3.-4. June: 123125

SHERRY, H.S. 1993: The cation-exchange properties of zeolites: A review. ZEOLITE'93, 4th International Conference on the Occurrence, Properties, and Utilization of Natural Zeolites, Boise-Idaho. June 20-28, 1993: 189-191

TERAI, C., SHIMIZU. S., MATSUSHIMA, S., TANAKA, I., OKADA, Y., MIYAHARA, T., NAKAJI, S. 1996: Development of a potassium-specific adsorbent for direct hemoperfusion. Artif Organs 20: 1227-1232

TOMASEVIC-CANOVIC, M., DUMIC, M., VUKICEVIC, O., RADOSEVIC, P., GLISOVIC, L., RAJIC, I., PALIC,T. 1993: Adsorption of aflatoxin $\mathrm{B}_{1}$ and $\mathrm{G}_{2}$ on clinoptilolite. ZEOLITE'93, 4th International Conference on the Occurrence, Properties, and Utilization of Natural Zeolites, Boise-Idaho, June 20-28, 1993: 202-204

VAVROVÁ, M.. MUSATOVOVA, O., BARTHA, S. 1991: In vitro studies on the ability of natural zeolites to sorb some radionuclides. Isotopenpraxis 17: $325-327$

VRZGULA. L., SEIDEL, H. 1989: Sorption properties of natural zeolite (clinoptilolite) in rumen and abomasal fluid in vitro (In Slovak). Vet. Med. (Praha) 34: 537-544

Address for correspondence:

MVDr. Herbert Seidel

University of Veterinary Medicine

Komenského 73

SK-041 81 Košice

Slovak Republic

Phone: 421956332111

E-mail: seidel@vsvnov.uvm.sk 